\title{
Persepsi mahasiswa tentang efektivitas pembimbing klinik
}

\author{
Oktorullah Oktorullah ${ }^{1}$, Sri Hartati Pratiwi ${ }^{2}$, Dyah Setyorini ${ }^{3}$, Ryan Hara Permana ${ }^{4}$ \\ ${ }^{1,2,3,4}$ Fakultas Keperawatan, Universitas Padjadjaran, Indonesia \\ *Corresponding Author: ryan.hara@unpad.ac.id
}

\begin{abstract}
Abstrak
Pendahuluan: Pencapaian keterampilan klinik keperawatan sangat dipengaruhi oleh kualitas pembimbing klinik. Peran pembimbing klinik yang tidak efektif dapat menyebabkan rendahnya capaian kompetensi mahasiswa keperawatan. Penelitian ini bertujuan menginvestigasi persepsi mahasiswa tentang efektivitas pembimbing klinik. Metode: Metode penelitian menggunakan deskriptif kuantitatif dengan populasi, yaitu mahasiswa Program Profesi Ners Angkatan XXXVIII Fakultas Keperawatan Universitas Padjadjaran. Teknik sampling menggunakan total Sampling dengan sampel yaitu 124 orang. Instrumen menggunakan The Nursing Clinical Teacher Effectiveness Inventory (NCTEI) (Cronbach Alpha=0,79-0,89). Hasil: Persepsi mahasiswa terhadap efektivitas pembimbing klinik di RSUP Dr. Hasan Sadikin Bandung (RSHS) diniali lebih baik $(m e a n=261,28)$ dibandingkan dengan RSUD Dr. Slamet Garut (RSUD Garut) (mean=233,85). Subvariabel tertinggi pada pembimbing klinik di RSHS yaitu kemampuan mengajar (mean=5,75), sedangkan di RSUD Garut yaitu hubungan interpersonal (mean=5,12). Simpulan: Efektivitas pembimbing klinik di RSHS dipersepsikan lebih baik dibandingkan RSUD Garut. Institusi pendidikan perlu melakukan evaluasi dan pengembangan kapasitas dari pembimbing klinik secara berkala.
\end{abstract}

Kata kunci: Efektivitas; mahasiswa keperawatan; pembimbing klinik; Persepsi

\section{Student's perceptions about the effectiveness of clinical instructors}

\begin{abstract}
Introduction: The attainment of nursing clinical skills is strongly influenced by the quality of clinical instructor. The ineffective role of clinical instructor can lead to the low competency achievement of nursing students. This study aims to investigate the students' perceptions of the effectiveness of clinical instructor. Methods: The research method used a quantitative descriptive with population of Ners Profession Program students batch XXXVIII, Faculty of Nursing, Padjadjaran University. The sampling technique used total sampling with a sample of 124 people. The instrument used was The Nursing Clinical Teacher Effectiveness Inventory (NCTEI) (Knox \& Mogan, 1985) (Cronbach Alpha $=0.79-0.89)$. Results: Students' perceptions of the effectiveness of clinical instructor at Dr. Hasan Sadikin Bandung (RSHS) was rated as better (mean = 261.28) compared to RSUD Dr. Slamet Garut (Garut Hospital) (mean = 233.85). The highest score of subvariable for clinical instructor in RSHS was teaching ability (mean $=5.75)$, while in Garut Hospital, it was interpersonal relationships (mean $=5.12$ ). Conclusions: The effectiveness of clinical instructor in RSHS is perceived to be better than Garut Hospital. Educational institution involved needs to conduct evaluation and capacity building of clinical instructor periodically.
\end{abstract}

Keywords: Clinical instructor; effectiveness; nursing students; perception

How to Cite: Oktorullah, O., Pratiwi, S.H., Setyorini, D., \& Permana, R.H. (2020). Persepsi mahasiswa tentang efektivitas pembimbing klinik. NURSCOPE: Jurnal Penelitian dan Pemikiran IImiah Keperawatan, 6 (2), 66-73

\section{PENDAHULUAN}

Perawat merupakan profesi di bidang kesehatan dengan jumlah terbanyak di Indonesia. Menurut Pusat Pengkajian Pengolahan Data dan Informasi (P3DI), pendidikan keperawatan yang berkualitas sangat menentukan kualitas tenaga perawat profesional (Lestari, 2014). Dalam pendidikan profesi, pembelajaran sepenuhnya dilakukan di area praktik pelayanan kesehatan seperti rumah sakit dan Pusat Kesehatan Masyarakat (Puskesmas) (Siswanto \& Woferst, 2014). 
Keberhasilan pembelajaran klinik dapat dipengaruhi baik oleh faktor internal, maupun eksternal. Menurut Saputra dan Lisiswanti (2015), faktor internal terdiri dari pengetahuan, sikap, keterampilan mahasiswa, motivasi, karakteristik kepribadian, pengalaman, dan pelatihan dan gaya belajar. Sedangkan faktor eksternal terdiri dari metode pembelajaran yang digunakan, fasilitas, konten materi, lingkungan pembelajaran klinik, serta pembimbing klinik (Saputra \& Lisiswanti, 2015). Hal ini diperkuat oleh pernyataan Marlina (2017) bahwa dalam pencapaian kompetensi pembelajaran klinik peran pembimbing klinik sebagai faktor eksternal merupakan faktor yang paling berpengaruh meningkatkan kompetensi yang dicapai.

Asosiasi Institusi Pendidikan Ners Indonesia AIPNI (2016) menyatakan bahwa pembimbing klinik yaitu dosen yang ditugaskan mengajar di area praktik klinik, atau perawat senior yang bekerja di area praktik yang ditugaskan sebagai pembimbing klinik. Peran pembimbing klinik dapat mempengaruhi efektivitas dalam penyerapan ilmu dan pencapaian kompetensi pada pembelajaran klinik. Menurut Asda (2017), pengawasan dari pembimbing klinik berhubungan secara signifikan dengan prestasi belajar mahasiswa di area praktik klinik, sehingga pengawasan yang baik akan berdampak pada peningkatan prestasi belajar klinik mahasiswa. Hal ini didukung oleh penelitian Rofiqoh dan Nurmalia (2017) di Rumah Sakit Umum Daerah (RSUD) Tugorejo Semarang yang menyatakan bahwa perilaku efektif perawat dalam melakukan bimbingan klinik dapat memberikan dampak kepada mahasiswa untuk menjadikan perawat tersebut sebagai role model dalam melakukan perawatan profesional baik sikap maupun tindakannya.

Apabila pembelajaran klinik tidak efektif, maka kualitas pembelajaran mahasiswa tidak maksimal. Hal ini dapat mempengaruhi kompetensi yang akan dicapai mahasiswa tersebut. Hasil Preliminary Survey Nasional tentang pencapaian kompetensi perawat oleh Direktorat Jenderal Pendidikan Tinggi pada tahun 2011 menunjukkan bahwa perawat baru yang dinyatakan kompeten oleh perawat pelaksana hanya sebesar $45 \%$, dari persepsi yang diharapkan $89,1 \%$; perawat dinyatakan kompeten oleh pimpinan pelayanan kesehatan hanya $47,4 \%$, dari persepsi yang diharapkan $100 \%$; dan perawat dinyatakan kompeten oleh pengguna layanan sebesar 68,7\% dari persepsi yang diharapkan $92,3 \%$. Data tersebut menunjukkan bahwa masih banyak perawat baru yang masih belum kompeten dan salah satunya disebabkan oleh pembelajaran klinik yang belum optimal (Dirjendikti, 2011).

Pada penelitian ini efektivitas pembimbing klinik dinilai dari sisi persepsi mahasiswa karena persepsi mahasiswa terhadap kinerja pembimbing klinik dalam proses pembimbingan klinik di rumah sakit sangat menentukan penilaian mahasiswa terhadap kualitas proses pembimbingan praktik klinik di rumah sakit. Persepsi ini memegang peranan penting dalam pengambilan keputusan seseorang dalam menentukan sikap, salah satunya berperilaku pada pembelajaran klinik (Robbin \& Judge, 2008). Oleh karena itu, persepsi mahasiswa program profesi Ners mengenai efektivitas pembimbing klinik di rumah sakit penting untuk diteliti.

\section{METODE}

Penelitian ini menggunakan metode deskriptif kuantitatif dengan pendekatan cross-sectional. Populasi penelitian yaitu seluruh mahasiswa Fakultas Keperawatan Program Profesi Ners Angkatan XXXVIII yang sudah menjalani pembelajaran klinik Stase Keperawatan Medikal Bedah di RSUP Dr. Hasan Sadikin Bandung (RSHS) dan RSUD Dr. Slamet Garut (RSUD Garut). Teknik sampling menggunakan metode total sampling, dengan jumlah responden yang didapat yaitu 124 orang mahasiswa profesi Ners. 
Penelitian ini menggunakan kuesioner The Nursing Clinical Teacher Effectiveness Inventory (NCTEI) oleh Knox dan Mogan (1985). Pengumpulan data dilakukan selama tujuh hari mulai 23-30 Agustus 2020 dengan menggunakan aplikasi kuesioner daring yaitu Google Form. Data dianalisis dengan metode deskriptif kuantitatif untuk menggambarkan hasil dari masing-masing variabel penelitian.

\section{HASIL DAN PEMBAHASAN}

Pada Tabel 1, terlihat bahwa mahasiswa Program Profesi Ners Angkatan XXXVIII Fakultas Keperawatan Unpad memiliki persepsi baik mengenai efektivitas pembimbing klinik di RSUP Dr. Hasan Sadikin Bandung (mean $=261,28$ ) lebih tinggi dibandingkan pembimbing klinik di RSUD Dr. Slamet Garut (mean=233,85).

Tabel 1. Distribusi Frekuensi Persepsi Mahasiswa Tentang Efektivitas Pembimbing Klinik ( $n=124)$

\begin{tabular}{ccccc}
\hline Rumah Sakit & Mean & S.D & Max & Min \\
\hline RSHS & 261,28 & 34,32 & 329 & 103 \\
RSUD Garut & 233,85 & 44,86 & 329 & 105 \\
\hline
\end{tabular}

Tabel 2 menunjukkan bahwa kemampuan mengajar pembimbing klinik di RSUP Dr. Hasan Sadikin Bandung merupakan subvariabel yang dipersepsikan paling baik oleh mahasiswa (mean=5,75), sedangkan kepribadian pembimbing klinik merupakan subvaribel yang dipersepsikan kurang baik oleh mahasiswa dibandingkan subvariabel lainnya (mean=5,42). Tabel 4.3 diatas juga menunjukkan hubungan interpersonal pembimbing klinik di RSU Dr. Slamet Garut merupakan sebagai subvariabel yang dipersepsikan paling baik oleh mahasiswa (mean=5,12), sedangkan kemampuan mengajar pembimbing klinik merupakan subvaribel yang dipersepsikan kurang baik oleh mahasiswa dibandingkan subvariabel lainnya (mean=4,88).

Tabel 2. Distribusi Frekuensi Persepsi Mahasiswa Tentang Efektivitas Pembimbing Klinik berdasarkan 5 sub variabel $(n=124)$

\begin{tabular}{lcccc}
\hline \multicolumn{1}{c}{ Subvariabel } & Mean & S.D & Max & Min \\
\hline $\begin{array}{l}\text { Pembimbing Klinik di RSUP Dr. Hasan Sadikin Bandung } \\
\text { 1. Kemampuan Mengajar }\end{array}$ & & & & \\
2. Kompetensi Keperawatan & 5,75 & 0.201 & 119 & 40 \\
3. Kemampuan Evaluasi & 5,56 & 0.273 & 63 & 27 \\
4. Hubungan Interpersonal & 5,53 & 0.309 & 56 & 16 \\
5. Kepribadian & 5,47 & 0.130 & 42 & 9 \\
Pembimbing Klinik di RSUD Dr. Slamet Garut & 5,42 & 0.496 & 49 & 11 \\
1. Kemampuan Mengajar & & & & \\
2. Kompetensi Keperawatan & 4,88 & 0.207 & 119 & 44 \\
3. Kemampuan Evaluasi & 4,99 & 0.287 & 63 & 16 \\
4. Hubungan Interpersonal & 5,00 & 0.119 & 56 & 13 \\
5. Kepribadian & 5,12 & 0.110 & 42 & 6 \\
\hline
\end{tabular}

Hasil penelitian ini menunjukkan bahwa mahasiswa Program Profesi Ners Angkatan XXXVIII Fakultas Keperawatan Unpad memiliki persepsi yang baik mengenai efektivitas pembimbing klinik di RSUP Dr. Hasan Sadikin Bandung (mean=261,28) lebih tinggi dibandingkan pembimbing klinik di RSUD Dr. Slamet Garut (mean=233,85). Hasil pada penelitian ini selaras dengan penelitian oleh Rofiqoh dan Nurmalia (2017) yang menyatakan bahwa mahasiswa praktik klinik di RSUD Tugurejo Semarang secara umum memiliki persepsi yang baik (52.5\%) terhadap peran pembimbing klinik. 
Persepsi mahasiswa yang baik terkait efektivitas pembimbing klinik akan sangat berdampak pada capaian kompetensi klinik yang didapatkan dikarenakan persepsi memegang peranan penting bagi seseorang untuk mengambil keputusan dalam berperilaku. Dalam hal ini jika persepsi terhadap pembimbing klinik yang dimiliki baik maka akan berdampak pula pada perilaku dalam proses pembelajaran klinik yang dilaksanakan (Robbin \& Judge, 2008). Persepsi positif terhadap pembimbingan klinik juga merupakan sumber dorongan bagi mahasiswa dalam meraih capaian pembelajaran. Dengan adanya persepsi yang baik terhadap pembimbing klinik maka akan mempengaruhi efektivitas pembelajaran klinik. Hal ini sejalan dengan penelitian oleh Purwani (2010) yang menyatakan bahwa persepsi terhadap pembimbing klinik memiliki hubungan yang signifikan dengan motivasi belajar mahasiswa praktik klinik di RSUD Dr. Moewardi Surakarta.

Meskipun mahasiswa sudah memiliki persepsi yang baik terhadap efektivitas pembimbing klinik pada pembelajaran klinik Stase Keperawatan Medikal Bedah di RSUP Dr. Hasan Sadikin, namun mahasiswa juga masih memiliki persepsi yang buruk pada pembelajaran klinik Stase Keperawatan Medikal Bedah di RSUD Dr. Slamet Garut. Jika persepsi yang dimiliki buruk terhadap pembimbing klinik, maka akan berdampak sebaliknya yaitu efektivitas pembelajaran yang didapatkan terasa kurang. Hal ini didukung oleh penelitian Bobaya, Kiling, Laoh, \& Losu (2015) pada mahasiswa keperawatan yang mengungkapkan bahwa terdapat sebagian (57.64\%) mahasiswa yang memiliki persepsi kurang baik terhadap pembimbing klinik, dan terdapat $56,7 \%$ kompetensi pembelajaran klinik yang didapat tidak tercapai.

Pembimbing klinik sangat berperan dalam menentukan ketercapaian kompetensi pembelajaran klinik terutama terkait keselamatan pasien. Parsh (2009) menyatakan bahwa pembimbing klinik dengan kompetensi klinik yang rendah dapat menghambat mahasiswa untuk memperoleh pengetahuan dan keterampilan pada saat belajar di area klinik. Sand-Jecklin (2009) menegaskan bahwa kontribusi pembimbing klinik cukup besar dalam meningkatkan kualitas pembelajaran klinik.

Perbedaan hasil pada persepsi mahasiswa di kedua tempat praktek ini dikarenakan RSUP Dr. Hasan Sadikin Bandung diketahui sudah bekerjasama lebih dari 5 tahun dengan Fakultas Keperawatan Universitas Padjadjaran dalam melaksanakan Pendidikan bagi Program Profesi Ners. Dengan jangka waktu tersebut, sebagian besar pembimbing klinik sudah memiliki pengalaman yang mumpuni di dalam membimbing mahasiswa Profesi Ners di dalam pembelajaran klinik, selain itu seluruhnya juga sudah memperoleh pelatihan sebagai pembimbing klinik sehingga berdampak pula pada kemampuannya dalam membimbing dan dipersepsikan baik oleh para mahasiswanya. Sebaliknya, RSUD Dr. Slamet Garut baru bekerjasama dengan Fakultas Keperawatan Universitas Padjadjaran dalam melaksanakan pendidikan bagi Program Profesi Ners kurang lebih 2 tahun, dan para pembimbing klinik belum memiliki banyak pengalaman dan mengetahui karakteristik pembelajaran pada mahasiswa Profesi Ners di Unpad, sehingga lebih dari setengah mahasiswa masih mempersespsikan buruk pada efektivitas pembimbing klinik di RSUD Dr. Slamet Garut.

Pembimbing klinik yang efektif menurut persepsi mahasiswa di dalam penelitian ini didasarkan pada teori yang diungkapkan oleh Mogan dan Knox (1987) yang terdiri dari 5 komponen di antaranya adalah kemampuan mengajar, kemampuan evaluasi, kompetensi keperawatan, hubungan interpersonal, dan kepribadian. Berdasarkan hasil penelitian ini didapatkan bahwa aspek kemampuan mengajar memperoleh mean tertinggi (mean $=5,75$ ) sebagai aspek yang dipersepsikan baik oleh mahasiswa dibandingkan 4 aspek yang lain pada pembimbing klinik di RSUP Dr. Hasan Sadikin Bandung. Hasil pada penelitian ini sejalan dengan penelitian yang dilakukan di RSUD Tugorejo, Semarang oleh Rofiqoh dan Nurmalia (2017) pada mahasiswa keperawatan yang menyatakan bahwa kemampuan mengajar merupakan aspek yang paling tinggi $(55,9 \%)$ dipersepsikan baik oleh mahasiswa. Selain itu, 
Gangadharan et al. (2016) menyatakan bahwa kemampuan mengajar merupakan indikator yang paling kuat dalam mempengaruhi efektivitas bimbingan klinik.

Kemampuan mengajar dideskripsikan sebagai proses menyampaikan pengetahuan, kemampuan, sikap, dan pembentukan atmosfer pembelajaran di mana proses ini terjadi (Mogan \& Knox, 1987). Seorang pembimbing klinik di dalam membimbing pembelajaran klinik dinilai efektif dalam hal kemampuan mengajar jika ia mampu untuk mentransfer pengetahuan, sikap dan keterampilan dari pembimbing kepada mahasiswa selain itu juga mampu untuk membentuk atmosfir pembelajaran yang menunjang proses pembelajaran klinik yang berlangsung. Pada penelitian ini ditemukan bahwa kemampuan mengajar merupakan komponen utama yang dinilai baik oleh mahasiswa. Hal ini dapat terjadi karena dalam pembelajaran klinik yang telah dilalui, para mahasiswa merasakan keamanan dalam bertindak sebagai dampak dari pembimbing klinik yang berpengetahuan tinggi dan terampil dalam bertindak sebagai fasilitator pada setting klinis (Banan \& Elsharkawy, 2017). Hal ini juga selaras dengan Nelson (2011) yang menyatakan bahwa dalam pembelajaran pada setting klinis membutuhkan pembimbing klinik yang berpengetahuan serta berpengalaman dengan kemampuan untuk mengajar orang dewasa secara efektif.

Hasil pada penelitian ini juga menunjukkan bahwa bahwa aspek kepribadian memperoleh mean terendah (mean $=5,42$ ) sebagai aspek yang dipersepsikan kurang baik oleh mahasiswa dibandingkan 4 aspek yang lain pada pembimbing klinik di RSUP Dr. Hasan Sadikin Bandung. Hasil penelitian ini didukung oleh hasil penelitian Sumarni dan Sugiharti (2019) yang menjelaskan bahwa aspek kepribadian merupakan aspek yang memiliki nilai terendah pada efektivitas pembimbing klinik, hal ini dikarenakan sebagian besar mahasiswa kurang menyukai pembimbing kliniknya disebabkan sikap atau karakteristik yang ditunjukkan pembimbing klinik saat melakukan pembelajaran klinik. Aspek kepribadian ini menjadi salah satu aspek vital yang harus dimiliki oleh pembimbing klinik karena dapat berguna untuk mengelola stres pada saat mahasiswa menjalani pembelajaran klinik. Stres saat praktik klinik bisa terjadi karena mahasiswa takut melakukan kesalahan, dan takut pasien dan keluarga pasien menolak tindakan yang akan dilakukan oleh mereka (Suikkala et al., 2020). Dalam keadaan ini, karakteristik pribadi pembimbing klinik yang ramah dan suportif sangat penting bagi mahasiswa untuk mendukung dalam melakukan setiap tindakannya.

Persepsi mahasiswa mengenai efektivitas pembimbing klinik pada Stase Keperawatan Medikal Bedah di RSUD Dr. Slamet Garut di dalam penelitian ini menunjukkan hasil bahwa aspek hubungan interpersonal merupakan aspek yang memiliki mean tertinggi (mean=5,12) sebagai aspek yang dipersepsikan baik oleh mahasiswa. Hasil ini didukung oleh hasil penelitian Baker (2012) pada mahasiswa keperawatan senior yang sedang menjalani stase Keperawatan Medikal Bedah di salah satu universitas di North Carolina, Amerika Serikat menyatakan bahwa hubungan interpersonal merupakan aspek yang memiliki nilai mean tertinggi $(8,09)$ diantara 4 aspek lainnya, dengan kata lain pada aspek hubungan interpersonal menggambarkan karakteristik pembimbing klinik yang paling efektif yang dimiliki oleh mahasiswa selama pembelajaran klinik. Namun, hasil ini bertolak belakang dengan penelitian yang dilakukan oleh Dasila Prabha et al. (2016) pada mahasiswa keperawatan di India yang menjelaskan bahwa, baik dari karakteristik pembimbing klinik yang sebenarnya maupun dari yang diharapkan oleh mahasiswa, aspek hubungan interpersonal memiliki nilai mean terendah $(4,00 \& 5,82)$ dibandingkan dengan 4 aspek lainnya.

Hubungan interpersonal didefinisikan sebagai keadaan ketertarikan timbal balik atau komunikasi antara dua atau lebih orang namun tidak termasuk komunikasi terapeutik spesifik antara perawat dan pasien (Mogan \& Knox, 1987). Kemampuan seorang pembimbing klinik untuk dapat berinteraksi secara baik dengan mahasiswa merupakan salah satu komponen untuk menilai keefektifan 
pembimbing klinik. Seorang pembimbing klinik yang memiliki hubungan interpersonal yang baik ditandai dengan pembimbing yang dapat didekati, mendorong untuk saling menghormati, memberikan dukungan dan dorongan selama pembelajaran, serta mendengarkan dengan penuh perhatian (Nehring, 1990). Pada penelitian ini ditemukan bahwa hubungan interpersonal merupakan komponen utama yang dinilai baik oleh mahasiswa pada pembelajaran di RSUD Dr. Slamet Garut. Hal ini dapat terjadi karena dalam pembelajaran klinik yang telah dilalui, para mahasiswa merasakan bahwa pembimbing yang ada sudah menunjukkan karakteristik hubungan interpersonal yang baik sehingga hal tersebut berdampak pada kemudahan dalam berkomunikasi, mempererat hubungan peserta didik dengan pengajar, mengurangi stress serta meningkatkan pembelajaran (Mogan \& Knox, 1987).

Aspek kemampuan mengajar pembimbing klinik merupakan aspek yang memiliki mean terendah (mean $=4,88$ ) dipersepsikan kurang baik oleh mahasiswa saat melakukan pembelajaran klinik Stase Keperawatan Medikal Bedah di RSUD Dr. Slamet Garut. Hasil ini mendukung penelitian yang telah dilakukan oleh Baker (2012) di North Carolina, Amerika Serikat yang menyatakan bahwa kemampuan mengajar dipersepsikan paling buruk dari karakteristik pembimbing klinik yang pernah dirasakan oleh mahasiswa selama pembelajaran klinik. Hal ini dikarenakan menurut persepsi mahasiswa, pembimbing klinik yang ada belum memberikan kesempatan latihan secara khusus serta belum mengarahkan mahasiswa ke literatur yang berguna dalam keperawatan (Baker, 2012). Kenyataannya mahasiswa sendiri memerlukan lebih banyak latihan untuk mengasah aspek psikomotor yang dimilikinya sehingga bisa meningkatkan kemampuannya, selain itu mahasiswa juga dalam melaksanakan setiap tindakan harus mengetahui update dari prosedur tindakan yang ada berdasarkan literatur penelitian yang tentunya selalu berkembang setiap saat dengan tidak adanya aspek-aspek ini maka akan berdampak pada capaian kompetensi yang didapatkan oleh mahasiswa dan berdampak pula pada keefektivitasan pembelajaran klinik sehingga aspek kemampuan mengajar ini merupakan salah satu aspek yang penting untuk ditingkatkan.

Keterbatasan pada penelitian ini yaitu hanya meneliti pembimbing klinik secara keseluruhan menurut mahasiswa namun tidak spesifik melibatkan setiap pembimbing klinik, sehingga hasil yang didapatkan merupakan anggapan mahasiswa secara umum mengenai pembimbing klinik di suatu tempat pelaksanaan pembelajaran klinik. Selain itu, penelitian ini juga merupakan penelitian yang hanya dilihat dari persepsi mahasiswa saja, tidak mempertimbangkan persepsi dari pihak lain, seperti institusi pendidikan ataupun pembimbing klinik itu sendiri.

\section{SIMPULAN DAN SARAN}

Secara umum, mahasiswa PPN XXXVIII Fakultas Keperawatan Unpad memiliki persepsi yang lebih baik mengenai efektivitas pada pembimbing klinik di RSUP Dr. Hasan Sadikin Bandung dibandingkan dengan pembimbing klinik di RSUD Dr. Slamet Garut. Kemampuan mengajar pembimbing klinik di RSHS merupakan subvariabel yang dipersepsikan paling baik oleh mahasiswa, sedangkan kepribadian pembimbing klinik dipersepsikan kurang baik. Hasil lainnya menunjukkan bahwa hubungan interpersonal pembimbing klinik di RSU Dr. Slamet Garut merupakan subvariabel yang dipersepsikan paling baik, sedangkan kemampuan mengajar dipersepsikan kurang baik. Insitusi pendidikan keperawatan disarankan melakukan evaluasi pembelajaran klinik khususnya terkait dengan pembimbing klinik secara berkala untuk terus menjaga kualitas pembelajaran klinik. Perlu ada kolaborasi antara institusi pendidikan dan rumah sakit untuk mengembangkan program pengembangan kapasitas pembimbing klinik untuk meningkatkan kemampuan dan sebagai dukungan pengembangan profesional. Hal lain yang dapat dilakukan oleh institusi pendidikan adalah memperhatikan aspek kepribadian yang mendukung proses pembelajaran klinik saat melakukan rekrutmen pembimbing klinik. 


\section{DAFTAR PUSTAKA}

AIPNI. (2016). Kurikulum Inti Pendidikan Ners Indonesia (F. Haryati, H. Kamil, K. Ibrahim, \& M. Hadi (eds.). Jakarta: Asosiasi Institusi Pendidikan Ners Indonesia (AIPNI).

Asda, P. (2017). Hubungan Bimbingan Klinik Oleh Pembimbing Klinik Akademik Dengan Prestasi Belajar Klinik Mahasiswa Semester V DIII Keperawatan STIKES Wira Husada Tahun Ajaran 2010/2011. OpenAsda, Patria."Hubungan Bimbingan Klinik Oleh Pembimbing Klinik Akademik Dengan Prestasi Belajar Klinik Mahasiswa Semester, 503.

Baker, K. (2012). Senior Nursing Students' Perception of Clinical Teacher Behavior. Western North Carolina: Gardner-Webb University

Banan, S. H. A. E. L., \& Elsharkawy, N. (2017). Undergraduate nursing students' and clinical instructors' perception of the characteristics of an effective clinical instructor at the faculty of nursing, Cairo University. Cairo University American Journal of Nursing Science, 6(3), 185-192.

Bobaya, J., Kiling, M.A., Laoh, J.M., \& Losu, N. (2015). Hubungan Persepsi Mahasiswa tentang Pembimbing Klinik dengan Pencapaian Target Praktek Klinik Keperawatan Medikal Bedah. JUPERINDO, 4(1), 20-31

Dasila Prabha, K., Veer Bharti, V., Ponchitra, R., Divjya, K. Y., \& Singh, J. J. (2016). Perceptions of nursing students on clinical teaching behaviors of teaching faculty: Correlational survey design. Journal of Nursing and Health Science, 5(5), 37-41.

Dirjendikti. (2011). Standar Pendidikan Ners Indonesia. dikti.go.id

Gangadharan, P., Abdu AlWahed, M. A., \& Ali Assiri, M. M. (2016). Effectiveness of clinical teacher behaviors as perceived by nursing students, graduates and faculty of King Khalid University, College of Applied Medical science, Mohail, Kingdom of Saudi Arabia, 5(3), 651-656.

Knox, J. E., \& Mogan, J. (1985). Important clinical teacher behaviours as perceived by university nursing faculty, students and graduates. Journal of Advanced Nursing, 10(1), 25-30.

Lestari, T. R. P. (2014). Pendidikan Keperawatan: Upaya Menghasilkan Tenaga Perawat Berkualitas. Jurnal Aspirasi, 5(1), 1-10.

Marlina, T. T. (2017). A Description Study of Nursing Students in Clinical Practice. Jurnal Keperawatan Respati Yogyakarta, 4(3), 272-277.

Mogan, J., \& Knox, J. E. (1987). Characteristics of 'best'and 'worst'clinical teachers as perceived by university nursing faculty and students. Journal of Advanced Nursing, 12(3), 331-337.

Nehring, V. (1990). Nursing clinical teacher effectiveness inventory: A replication study of the characteristics of 'best'and 'worst'clinical teachers as perceived by nursing faculty and students. Journal of Advanced Nursing, 15(8), 934-940.

Nelson, N. (2011). Beginning nursing students' perceptions of the effective characteristics and caring behaviors of their clinical instructor. Capella University. 
Parsh, B. (2009). Nursing student and faculty perceptions of the characteristics of effective instructors in the simulated clinical experience.

Purwani, F. (2010). Hubungan antara persepsi mahasiswa terhadap pembimbingan klinik dan motivasi belajar praktik klinik di RSUD Dr. Moewardi Surakarta.

Robbin, S., \& Judge, T. A. (2008). Perilaku Organisasi Edisi 12. Jakarta: Selemba Empat.

Rofiqoh, I., \& Nurmalia, D. (2017). Persepsi Mahasiswa Praktik Keperawatang Tentang Peran Pendidik Klinik di RSUD Tugurejo Semarang. Diponegoro Universty.

Sand-Jecklin, K. (2009). Assessing nursing student perceptions of the clinical learning environment: refinement and testing of the SECEE inventory. Journal of Nursing Measurement, 17(3), 232-246.

Saputra, O., \& Lisiswanti, R. (2015). Faktor-faktor yang mempengaruhi keberhasilan pembelajaran keterampilan klinik di Institusi Pendidikan Kedokteran. Juke Unila, 5(9), 104-109.

Siswanto, F., \& Woferst, R. (2014). Faktor-Faktor yang Berhubungan dengan Motivasi Mahasiswa untuk Melanjutkan Profesi Ners. Riau University.

Suikkala, A., Leino-Kilpi, H., Katajisto, J., \& Koskinen, S. (2020). Nursing student-patient relationship and related factors-A self-assessment by nursing students. Journal of Clinical Nursing, 29(2122), 4030-4044.

Sumarni, T., \& Sugiharti, R. K. (2019). Persepsi Mahasiswa Ners Universitas Harapan Bangsa Tentang Pembimbing Klinik. Jurnal Smart Keperawatan, 6(1), 25-30. 